\title{
Procedural Rules in the Service of the 'Transformative Function' of EU Equality Law: Bringing the Prohibition of Nationality Discrimination Along
}

Elise Muir*

Associate Professor and Veni Research Fellow at the Maastricht Centre for European

Law

\section{Abstract}

Over the years, EU equality legislation (partly relying on CJEU case law) has built a set of rules concerned with access to courts at the domestic level as well as remedies. These rules can be described as the 'common procedural law of EU equality policy'. Regrettably, the legislative framework for the prohibition of nationality discrimination has remained an exception to this trend. The approximation of the technicalities giving effect to EU rules on the prohibition of nationality discrimination with those on the prohibition of discrimination on grounds of sex, race/ethnic origin, religion/belief, sexual orientation, age, and disability has only recently been initiated thanks to Directive 2014/54. It will be argued that this new Directive brings the prohibition of nationality one step closer to the fundamental rights rationale that lies behind the prohibition of other grounds of discrimination at the EU level.

\section{Introduction}

The "proceduralisation" process which is the focus of this Special Issue is clearly visible in the context of EU equality law. EU equality legislation has long included provisions related to access to justice but there has been an intensification of the process since the entry into force of the Amsterdam Treaty. The evolution of the procedural rules contained in EU equality law have followed a dynamic that may be perceived as counterintuitive when compared with the evolution of the relevant substantive provisions. The most recent areas of EU equality law have been 'proceduralised' to a much greater extent than the well established areas of EU equality law.

* DOI $10.7590 / 187479815 X_{14313382198458}$

1 As defined in the Editorial and Concluding contribution of this Special Issue. Note that the expression is borrowed from the French, see for instance E. Bribosia, 'La lutte contre les discriminations dans l'Union européenne: une mosaïque de sources dessinant une approche différenciée', in : C. Bayart, S. Sottiaux \& S. van Drooghenbroack (Eds), Les nouvelles lois luttant contre les discriminations (Bruges, Bruxelles: die Keure, la charte 2008) 47; R. Gellert \& P. De Hert, 'La non-discrimination comme réalité effective en Europe ? Réflexions sur la procéduralisation du droit de l'égalité européen' [2012/1] Revue belge de droit constitutionnel 7 . 
As rules on access to justice and judicial remedies are deemed to give effect to EU substantive rules, it is important to sketch out the bulk of the substantive rules on the prohibition of discrimination and point out their underlying rationale at this preliminary stage before investigating their procedural spillover effects. ${ }^{2}$ EU equality law finds its origin ${ }^{3}$ in the Treaty of Rome, with the prohibition of discrimination on grounds of nationality of an EU citizen ${ }^{4}$ exercising an economic activity with a cross-border dimension, and the prohibition of discrimination in wages between men and women. The prohibition of nationality discrimination has developed since the late $1980 \mathrm{~s}^{5}$ to protect not only EU citizens engaged or having engaged in cross-border ${ }^{6}$ economic activities but also all those benefiting from the right to free movement in other ways (such as students). ${ }^{7}$ In contrast with other prongs of EU equality law, the prohibition of nationality discrimination only benefits EU citizens and those EU citizens whose situation has cross-border implications.

The prohibition of discrimination on grounds of sex in wages also developed to cover a much broader range of rights than the initial wording of the Treaty suggested. It grew to encompass employment related rights, ${ }^{8}$ social security, ${ }^{9}$ self-employment ${ }^{10}$ in the 1970 s and 1980 s and more recently, since 2004 , access to goods and services. ${ }^{11}$ As shown below, the prohibition of sex discrimination

2 This paper focuses on EU rules by which the Treaty makers or the EU legislator give specific expression to the principle of non-discrimination with a view to achieving a more egalitarian society. Thus leaving aside the general principle of equal treatment and expressions of the principle enshrined in EU policies that are not specifically focused on giving effect to this principle.

3 See also G. More, 'The principle of equal treatment: from market unifier to fundamental right', in: P. Craig \& G. de Búrca, The evolution of EU law (1st Edition, OUP) and M. Bell, 'The principle of equal treatment: widening and deepening', in: P. Craig \& G. de Búrca, The evolution of EU law (2nd Edition, OUP).

4 Although this only became clear through case law of the CJEU; e.g. Joined Cases C-22/08 and C-23/08 Vatsouras [2009] ECR I-4585.

5 See S. O'Leary, 'Putting flesh on the bones of European citizenship' [1999/24] European Law Review 68-79.

6 I will not elaborate on the complex case law of the CJEU on the requirement for a 'cross-border' element which is beyond the scope of this article.

7 See Directive $2004 / 38$ on the right of citizens of the Union and their family members to move and reside freely within the territory of the Member States [2004] OJ L158/77.

8 See Directive $2006 / 54$ on the implementation of the principle of equal opportunities and equal treatment of men and women in matters of employment and occupation (recast) [2006] OJ L204/23.

9 Directive $79 / 7$ on the progressive implementation of the principle of equal treatment for men and women in matters of social security [1979] OJ L6/24 is still applicable.

10 See Directive $2010 / 41$ on the application of the principle of equal treatment between men and women engaged in an activity in a self-employed capacity [2010] OJ L180/1.

11 Directive 2004/113 implementing the principle of equal treatment between men and women in the access to and supply of goods and services [2004] OJ L373/37 the adoption of which was only made possible owing to the new Art. 13 TEC inserted by the Treaty of Amsterdam. 
has been at the fore front of 'legal' innovation - both judicial and legislative in the field of EU equality law.

Nevertheless, the entry into force of the Treaty of Amsterdam paved the way for the legislature to tackle other types of discrimination and to build on earlier developments while modernising EU equality law. Two key instruments were indeed swiftly adopted. The first prohibits discrimination on grounds of race or ethnic origin in employment as well as beyond (Racial Equality Directive). ${ }^{12}$ The second tackles discrimination on grounds of religion or belief, age, sexual orientation or disability in employment (Employment Directive). ${ }^{13}$

These various provisions constitute a set of norms that is remarkably ambitious and sophisticated. The prohibition of discrimination is not only ambitious due to the number of grounds and fields it covers but also because, unlike other international instruments, it regulates both vertical and horizontal relationships. The horizontal application of the prohibition of nationality discrimination has remained controversial until recently, ${ }^{14}$ and this specific branch of EU equality law remains tainted with a stronger economic rationale. In contrast, it is unquestionable from the wording of the relevant legislation that the other prongs of EU equality law are destined to give expression to a fundamental right and to apply in inter-personal relationships.

In so far as EU equality law is thereby intended to 'transform'15 societal habits and contribute to 'inter-personal equality per se, ${ }^{16}$ the relevant legislative framework appears to be particularly sophisticated (when compared for instance with earlier national equality law regimes but also when compared to the law of the ECHR). In terms of substance, EU equality legislation usually prohibits direct as well as indirect discrimination, harassment and retaliation, tolerates certain forms of positive action and also demands reasonable accommodation in well defined circumstances. ${ }^{17}$ Nevertheless, and despite the wealth of case law in the field, the prohibition of discrimination on grounds of nationality has

12 Directive 2000/43 implementing the principle of equal treatment between persons irrespective of racial or ethnic origin [2000] OJ L180/22.

13 Directive $2000 / 78$ establishing a general framework for equal treatment in employment and occupation [2000] OJ L303/16.

14 See further below.

15 See further E. Muir, 'The transformative function of EU equality law' [2013/21-5] European Review of Private Law 1231-1254. The expression 'transformative' applied in this context is borrowed from A. Stone Sweet \& K. Stranz, 'Rights Adjudication and Constitutional Pluralism in Germany and Europe' [2012/19-1] Journal of European Public Policy 96.

16 F.W. Scharpf, 'Perpetual Momentum: Directed and Unconstrained?' [2012/19-1] Journal of European Public Policy 127, at 132-3.

17 This dimension of EU equality law has been subject to much attention and research: e.g. M. Bell, Anti-Discrimination Law and the European Union (OUP 2002). 
not been accompanied by any legislative guidance on the concept of discrimination to date.

As regards procedural rules intended to enhance the effectiveness of the prohibition of discrimination, the EU legislature has also built over the years (interactively with CJEU case law) a set of rules concerned with access to courts at the domestic level and remedies ${ }^{18}$ as well as with 'para-legal' avenues to combat discrimination. ${ }^{19}$ Once again, it is remarkable that the legislative framework for the prohibition of nationality discrimination has remained an exception to this trend.

Yet, the approximation of rules on the technicalities giving effect to EU rules on the prohibition of discrimination on grounds of sex, race/ethnic origin, religion/belief, sexual orientation, age, disability with those giving effect to the prohibition of nationality discrimination has recently been initiated owing to the adoption of Directive 2014/54 (on measures facilitating the exercise of rights conferred on workers in the context of freedom of movement for workers). ${ }^{20}$

This contribution argues that Directive 2014/54 illustrates that the process of proceduralisation, if adequately implemented at domestic level and monitored at the EU level, is capable of significantly modifying the 'enforcement culture ${ }^{21}$ of EU law prohibiting nationality discrimination. It can indeed bring it closer to that currently in use for the other grounds of discrimination covered by EU law. In order to reach this point, two questions will be examined in turn. Firstly, does EU equality law provide for a coherent set of constraints on domestic judicial systems? Or, in other words, are the implications of the prohibition of nationality discrimination for access to justice and judicial remedies at domestic level consistent with those existing in other prongs of EU equality law? Secondly, how does this affect the relationship between the prohibition of discrimination on grounds of nationality and the other branches of EU equality law?

The evolution of the rules on access to justice and judicial remedies contained in the legislative framework implementing the principle of equal treatment on

18 See also R. Gellert \& P. De Hert, 'La non-discrimination comme réalité effective en Europe ? Réflexions sur la procéduralisation du droit de l'égalité européen' [2012/1] Revue belge de droit constitutionnel 7, at 23 .

19 G. de Búrca, 'EU Race Discrimination Law: a Hybrid Model?’, in: G. de Búrca \& J. Scott (Eds), Law and New Governance in the EU and the US (2006).

20 Directive 2014/54 on measures facilitating the exercise of rights conferred on workers in the context of freedom of movement for workers OJ [2014] L128/8.

21 The author is grateful to Orla Lynskey for suggesting this expression during the workshop on which this Special Issue is based: 'Proceduralisation of EU law through the backdoor', Faculty of Law of Maastricht University, Brussels Campus, 20-21 October 2014. 
grounds of sex, race/ethnic origin, religion/belief, sexual orientation, age, and disability shed light on the 'transformative' function that these rules are intended to play in the EU legal order (section 2). Although not identical, the newly adopted rules giving effect to the prohibition of nationality discrimination against mobile EU workers ${ }^{22}$ and their families (as well as facilitating the exercise of rights conferred on workers in the context of freedom of movement for workers) are very similar to the existing procedural framework for the protection against discrimination in the EU (section 3). It will be stressed that this process of proceduralisation that is - at last - reaching the prohibition of nationality discrimination allows for a more firm assertion ${ }^{23}$ of the horizontal implications of the prohibition of discrimination on grounds of nationality. It also enables a tightening of its connection with the fundamental rights rationale of EU equality law.

\section{The 'Ages' of the Proceduralisation of EU Equality Policy: Asserting the 'Transformative' Function of this Field of EU Law}

As the scope of EU equality law grew (section 2.1), so did the procedural rules designed to give it effect, and now the area constitutes an extraordinary set of norms (section 2.2) giving effect to a fundamental right at the supranational level (section 2.3).

\subsection{The Coming of Age of the Procedural Law of EU Equality Policy}

From the 1970s onwards, the first directives on the prohibition of sex discrimination in employment, self-employment and social security included a set of provisions concerned with access to justice and judicial remedies. All the relevant instruments featured a clause requiring that those who consider themselves wronged as a result of a breach of the directives to "pursue their claims by judicial process after possible recourse to other competent authorities'. ${ }^{24}$ These directives also included a requirement to protect employees against

22 It may be recalled that Article 45 TFEU on the free movement of EU workers which is used to define the personal scope of Directive 2014/54 has been interpreted to also include jobseekers: Case C-292/89 Antonissen ECR [1991] I-745, paras 11-14.

23 Although not departing from the requirement that the sponsor of the right be an EU citizen and that the situation has a cross-border dimension.

24 Directive 75/117 on the approximation of the laws of the Member States relating to the application of the principle of equal pay for men and women OJ [1975] L45/19, Art. 2; see also Directive $76 / 207$ on the implementation of the principle of equal treatment for men and women as regards access to employment, vocational training and promotion, and working conditions $O J$ [1976] L39/40, Art. 6; Directive 79/7 on the progressive implementation of the principle of equal treatment for men and women in matters of social security OJ [1979] L6/24, Art. 6; Di- 
dismissal that could result from a measure taken by the employer against those bringing a complaint on the basis of the directives. ${ }^{25}$ Case law of the CJEU interpreting these provisions extended the protection to cover other forms of retaliation. ${ }^{26}$ The Equal Pay Directive, the first of the directives, adopted in early 1975 , also included an 'avant-garde' provision ${ }^{27}$ referring to the principle of 'effectiveness' and requiring that the

'Member States shall, in accordance with their national circumstances and legal systems, take the measures necessary to ensure that the principle of equal pay is applied. They shall see that effective means are available to take care that this principle is observed'. ${ }^{28}$

After this promising infancy, the proceduralisation of EU sex equality law has been marked by a significant addition in the 1990s. Building on case law of the CJEU, ${ }^{29}$ the EU legislature adopted an instrument of a purely procedural nature: the so-called 'Burden of Proof Directive'. ${ }^{30}$ This directive organised a partial shift in the burden of proof in sex discrimination cases. The Member States must make sure, subject to limited exceptions, ${ }^{31}$ that the applicant only needs to establish facts from which it may be presumed that there has been discrimination. The burden of proof is then passed on the respondent for him

rective $86 / 378$ on the implementation of the principle of equal treatment for men and women in occupational social security schemes OJ [1986] L225/4O, Art. 10; Directive 86/613 on the application of the principle of equal treatment between men and women engaged in an activity, including agriculture, in a self-employed capacity, and on the protection of self-employed women during pregnancy and motherhood OJ [1986] L359/56. Art. 9; see also Directive 92/85 on the introduction of measures to encourage improvements in the safety and health at work of pregnant workers and workers who have recently given birth or are breastfeeding OJ [1992] L348/1, Art. 12. It may be recalled that the first CJEU case on the horizontal direct effect of Treaty provisions is the Defrenne case on the principle of equal pay between men and women: Case 43/75 Defrenne v. Sabena [1976] ECR I-455.

25 Such provisions that protect 'employees' only appear in the employment related directives and do not have an equivalent in the self-employed directive and statutory social security schemes directive.

26 Case C-185/97 Coote [1998] ECR I-5199.

27 See Case C-33/76 Rewe [1976] ECR 1989; see further the contribution by O. Dubos in this Special Issue, Section 1.1.2.

28 Directive 75/117 supra note 30, Art. 6. As the formula is very broad, it would be understood as encouraging the Member States, among other things, to ensure efficient access to justice and judicial forms of redress.

29 Case C-94/10 Danfoss [2011] ECR I-9963; Case C-127/92 Enderby [1993] I-5535 on pay.

30 Directive $97 / 80$ on the burden of proof in cases of discrimination based on sex OJ [1998] L14/6. It was adopted on the basis of Art. 2(2) of the Social Protocol annexed to the Treaty establishing the European Community after the Treaty of Maastricht.

31 This does not apply to proceedings in which it is for the court or competent body to investigate the facts of the case. Also note that Member States may have rules of evidence which are more favourable to plaintiffs. 
or her to prove the absence of a breach of the principle of equal treatment. ${ }^{32}$ This directive thus made it easier for applicants to enforce their right to equal treatment on grounds of sex in pay and employment as well as under the directives on pregnant workers and parental leave. ${ }^{33}$

Yet, the set of procedural rules giving effect to EU equality law genuinely became more mature after the adoption of the Racial Equality Directive and the Employment Directive (covering discrimination on grounds of religion/belief, age, sexual orientation, disability) following up on the entry into force of the Amsterdam Treaty. Both instruments as well as the subsequent re-casts (Directive on employment and Directive on self-employment), ${ }^{34}$ broadening (Directive on access to and supply of goods and services $)^{35}$ and modernisation of EU sex equality law included even more advanced procedural rules. Although located in different parts of each of these five directives and not always strictly identical, the procedural provisions of the current EU equality legislation ${ }^{36}$ are very similar. This means they can be presented together and largely understood as a common procedural law of EU anti-discrimination policy.

\subsection{The Common Procedural Law of EU Equality Policy}

Leaving aside the non-judicial aspects of this common procedural law, ${ }^{37}$ five key elements recur in most of the legislative instruments covering the prohibition of discrimination on grounds of sex, ethnic origin/race, religion/belief, age, sexual orientation and disability. While some of these elements merely strengthen earlier developments, others are more innovative. The following analysis of each of these five key elements is illustrated with quotations extracted from the Racial Equality Directive that has to a large extent been used as a source of inspiration for the other ones.

32 Directive 97/80 supra note 30, Art. 4 .

33 Directives $75 / 117,76 / 207$ and $92 / 85$ supra note 24 as well as to Directive $96 / 34$ on parental leave OJ [1996] L145/4 in so far as sex discrimination is concerned but not to social security schemes and self-employment.

34 Directive 2006/54 (on employment) and Directive 2010/41 (on self-employment), supra notes 8 and 10.

35 Directive 2004/113 (on access to and supply of goods and services), supra note 11.

36 With the notable exception of the Directive on equal treatment on grounds of sex in statutory social security schemes.

37 These fall beyond the scope of this Special Issue and article. 


\subsubsection{Access to Judicial and/or Administrative Procedures}

To start with, all five directives include a provision on access to judicial and/or administrative procedures ${ }^{38}$ modeled on Article 7 of the Racial Equality Directive which is entitled 'Defence of rights' and states as follows:

'1. Member States shall ensure that judicial and/or administrative procedures, including where they deem it appropriate conciliation procedures, for the enforcement of obligations under this Directive are available to all persons who consider themselves wronged by failure to apply the principle of equal treatment to them, even after the relationship in which the discrimination is alleged to have occurred has ended.

2. Member States shall ensure that associations, organisations or other legal entities, which have, in accordance with the criteria laid down by their national law, a legitimate interest in ensuring that the provisions of this Directive are complied with, may engage, either on behalf or in support of the complainant, with his or her approval, in any judicial and/or administrative procedure provided for the enforcement of obligations under this Directive.

3. Paragraphs 1 and 2 are without prejudice to national rules relating to time limits for bringing actions as regards the principle of equality of treatment' ${ }^{39}$

This provision is significantly more elaborate than its predecessor - the sex equality directives from the 1970 s and 1980 s quoted above. ${ }^{40}$ The main additional feature is the necessity ${ }^{41}$ for the Member States to ensure that selected legal entities may engage in judicial and/or administrative procedures to combat discrimination. These entities are meant to facilitate private enforcement of EU equality law by acting on behalf or in support of the claimant and with the approval of the person. ${ }^{42}$ In the context of sex equality law, the Commission has further recommended that equality bodies (which will be introduced below in section 2.2.4) be enabled to represent individuals in equal pay claims and ensure coordination and cooperation with labour market inspection authorities. ${ }^{43}$

Directive 2000/78, Art. 9; Directive 2004/113, Art. 8(1) \& (3-4); Directive 2010/41, Art. 9. Directive $2006 / 54$, Art. 17 only refers to judicial remedies.

39 Racial Equality Directive, Art. 7.

40 See supra note 24.

41 See for instance Racial Equality Directive, Art. 7(2).

42 For an overview of national implementing measures see the European Commission report 'Developing Anti-Discrimination Law in Europe: The 28 EU Member States, the Former Yugoslav Republic of Macedonia, Iceland, Liechtenstein, Norway and Turkey compared' (October 2013, available at http://www.non-discrimination.net/content/media/Developing\% 20Anti-Discrimination\%20Law\%20in\%2oEurope\%20EN\%2029042014\%20WEB.pdf), p. 121. Recommendation $\operatorname{COM}(2014) 124$ on strengthening the principle of equal pay between men and women through transparency OJ [2014] L69/112, points 14-15. 
Meanwhile the Commission is also steering an intense reflection on the collective enforcement of EU law ${ }^{44}$ that would go beyond private enforcement ${ }^{45}$ and may have interesting implications for EU equality law in the future. ${ }^{46}$

\subsubsection{Partial Shift in the Burden of Proof}

The second procedural element builds on the acquis of the directive that led to a partial shift of the burden of proof in sex equality case. ${ }^{47}$ Yet, its scope is now much broader since it covers the four directives examined in this section - with the exception of the Directive on sex equality in self-employment. By way of example, Article 8 of the Racial Equality Directive on 'Burden of proof' reads:

'1. Member States shall take such measures as are necessary, in accordance with their national judicial systems, to ensure that, when persons who consider themselves wronged because the principle of equal treatment has not been applied to them establish, before a court or other competent authority, facts from which it may be presumed that there has been direct or indirect discrimination, it shall be for the respondent to prove that there has been no breach of the principle of equal treatment.

2. Paragraph 1 shall not prevent Member States from introducing rules of evidence which are more favourable to plaintiffs.

3. Paragraph 1 shall not apply to criminal procedures.

4. Paragraphs 1, 2 and 3 shall also apply to any proceedings brought in accordance with Article $7(2)$.

5. Member States need not apply paragraph 1 to proceedings in which it is for the court or competent body to investigate the facts of the case'. ${ }^{48}$

It is worth noting that the partial shift in the burden of proof will also operate when selected legal entities act in support or on behalf of the claimant as enabled by provisions such as Article 7(2) of the Racial Equality Directive. The intent of the legislature is thus indeed to make it easier for victims to bring their claims to court and create a presumption of discrimination.

44 Recommendation $\operatorname{COM}(2013) 3539$ on common principles for injunctive and compensatory collective redress mechanisms in the Member States concerning violations of rights granted under Union Law OJ [2013] L201/6o.

45 On the distinction between public, collective and private enforcement in EU equality law see: M. Dawson, E. Muir \& M. Claes, 'Enforcing the EU's rights revolution: the case of Equality' [2012/3] European Human Rights Law Review 276-291.

46 Illustrating current reflections on the matter: L. Farkas, 'Collective Action under European anti-discrimination law' [2014/19] European Anti-Discrimination Law Review 25-40.

47 Supra note 32.

48 Racial Equality Directive, Art. 8. 


\subsubsection{Victimisation}

The third component of the common procedural law of EU equality policy relates to the protection against retaliation and also builds on earlier legislative and judicial developments. ${ }^{49}$ Indeed it is very similar to the wording of the early legislation on sex equality but now covers a broad range of adverse consequences affecting the person bringing a complaint and now is applicable to four of the five directives (leaving aside the Directive on sex equality in self-employment) in terms similar to those of Article 9 of the Racial Equality Directive on 'Victimisation': ${ }^{\circ}$

'Member States shall introduce into their national legal systems such measures as are necessary to protect individuals from any adverse treatment or adverse consequence as a reaction to a complaint or to proceedings aimed at enforcing compliance with the principle of equal treatment'. ${ }^{51}$

\subsubsection{Specialised Bodies \& their Relationship to Courts}

The main innovation brought by the 'procedural package' contained in the new Directives after the entry into force of the Lisbon Treaty (with the regrettable exception of the Employment Directive) relates to 'Bodies for the promotion of equal treatment' according to the Racial Equality Directive. ${ }^{52}$ Although the wording differs slightly in the four directives concerned, the relevant provisions are once again largely modeled on the Racial Equality Directive in its Article 13:

1. Member States shall designate a body or bodies for the promotion of equal treatment of all persons without discrimination on the grounds of racial or ethnic origin. These bodies may form part of agencies charged at national level with the defence of human rights or the safeguard of individuals' rights.

2. Member States shall ensure that the competences of these bodies include: - without prejudice to the right of victims and of associations, organisations or other legal entities referred to in Article 7(2), providing independent assistance to victims of discrimination in pursuing their complaints about discrimination,

- conducting independent surveys concerning discrimination,

\footnotetext{
Supra notes 25 and 26.

Directive 2000/78, Art. 11; Directive 2004/113, Art. 10; Directive 2006/54, Art. 24.

Racial Equality Directive, Art. 9.

See also Directive 2004/113, Art. 12; Directive 2006/54, Art. 20; Directive 2010/41, Art. 11.
} 
- publishing independent reports and making recommendations on any issue relating to such discrimination. ${ }^{53}$

Member States are thus required to create or designate organs for the promotion of equal treatment. One of the minimum attributes ${ }^{54}$ of these equality bodies is to assist victims to pursue complaints. As indicated above, the Commission recommends enabling these bodies to represent individuals in equal pay claims and ensure coordination and cooperation with labour market inspection authorities ${ }^{55}$ thus going one step further than the equality directives require. Another important nuance in more recent equality directives relates to the possibility for these domestic bodies to exchange information with corresponding European bodies. ${ }^{56}$

Together with the provisions designed to allow selected legal entities such as non-governmental organisations to support private litigants ${ }^{57}$ and the reorganisation of the burden of proof in discrimination cases, ${ }^{58}$ equality bodies are thus intended to develop a new enforcement culture. It is hoped that these procedural tools can contribute to fulfilling the transformative function of EU equality law by facilitating access to justice and to redress mechanisms.

\subsubsection{Sanctions, Penalties, Compensation and Reparation}

This is further exemplified by the last component of the common procedural framework for EU equality law that relates to sanctions, penalties, compensation and reparation depending on the wording of each of the directives. These rules build on the 'avant-garde' provision inserted in the Equal Pay Directive from 1975 mentioned above ${ }^{59}$ but go several steps beyond. They require the adoption of sanction mechanisms as well as a possibility of compensation to the victim. ${ }^{6 \circ}$ A Commission Recommendation further stresses the importance of remedies in cases concerning equal pay between men and

53 Racial Equality Directive, Art. 13.

54 In practice, many Member States now have bodies that have a quasi-judicial function. For an overview of the competences of these national bodies see: European Commission, 'Developing Anti-Discrimination Law in Europe' (October 2013, available at www.non-discrimination.net/ content/media/Developing\%2oAnti-Discrimination\%2oLaw\%2oin\%2oEurope\% 20EN\%2029042014\%20WEB.pdf), p. 122-125 and 155 et seq.

55 Recommendation $\operatorname{COM}(2014) 124$, supra note 43, points 14-15.

56 Directive 2006/54, Art. 20 and Directive 2010/41, Art. 11.

57 Supra section 2.2.1.

58 Supra section 2.2.2.

59 Supra note 28.

6o This can also be read in conjunction with the case law of the CJEU in the field of sex equality: Case C-14/83 von Colson [1984] ECR 1891 and Case C-212/94 Marshall II [1996] ECR I-389. 
women $^{61}$ and a Council Framework Decision goes as far as encouraging the Member States to make use of criminal law in relation to certain forms and expressions of racism and xenophobia (although this instrument goes beyond the substantive scope of the Racial Equality Directive). ${ }^{62}$

On this matter, the wording of the equality directives vary significantly. Article 15 of the oldest of the post-Amsterdam directives, the Racial Equality Directive, refers to the need for Member States to introduce sanctions that may include compensation: ${ }^{63}$

'Member States shall lay down the rules on sanctions applicable to infringements of the national provisions adopted pursuant to this Directive and shall take all measures necessary to ensure that they are applied. The sanctions, which may comprise the payment of compensation to the victim, must be effective, proportionate and dissuasive. The Member States shall notify those provisions to the Commission by 19 July 2003 at the latest and shall notify it without delay of any subsequent amendment affecting them. ${ }^{, 64}$

More recent directives are slightly more prescriptive and have a different focus. ${ }^{65}$ The latest one, the Directive on sex equality in self-employment, focuses on compensation or reparation and prohibits the fixing of an upper limit. Its Article 10 reads as follows:

'The Member States shall introduce such measures into their national legal systems as are necessary to ensure real and effective compensation or reparation, as Member States so determine, for the loss or damage sustained by a person as a result of discrimination on grounds of sex, such compensation or reparation being dissuasive and proportionate to the loss or damage suffered. Such compensation or reparation shall not be limited by the fixing of a prior upper limit'. ${ }^{66}$

In essence, these provisions largely echo the case law of the CJEU on the principle of effectiveness as a limitation on Member State's procedural autonomy. Nevertheless, it is interesting to observe a change in the tone used. Rules that were initially designed to primarily serve the purpose of penalising

61 Recommendation $\operatorname{COM}(2014) 124$, supra note 43, point 16.

62 Framework Decision 2008/913 on combating certain forms and expressions of racism and xenophobia by means of criminal law $O J$ [2008] L328/55.

63 See also Directive 2000/78, Art. 17; Directive 2004/113, Art. 14.

64 Racial Equality Directive, Art. 15.

65 See also Directive 2006/54, Art. 18; Directive 2004/113, Art. 8(2).

66 Directive 2010/41, Art. 10. 
are amended with a new ${ }^{67}$ (complementary) focus on compensation or reparation. This suggests a concern to better combine the private interest of the victims with the broader (public) concern to punish as well as dissuade. ${ }^{68}$

The common procedural law of EU anti-discrimination policy thus covers access to justice (or administrative procedures) with support from legitimately interested entities, a partial shift in the burden of proof, protection against retaliation in case of complaints, the creation of specialised bodies for the promotion of equal treatment as well as a rough framework for sanctions and compensation. In other words, it is geared towards supporting complainants.

\subsection{EU Procedural Equality Law as a Key Component of the 'First' Fundamental Rights Policy of the EU}

The emergence of this common procedural law of EU antidiscrimination policy can be related to institutional as well as teleological factors.

From an institutional perspective, it may be recalled that equality law is a field of EU policy that is known for having been strongly driven by judicial developments. ${ }^{69}$ While this observation primarily refers to substantive equality legislation, it also applies to the development of its procedural dimension. For instance, the reorganisation of the burden of proof as well as the requirement for efficient and dissuasive sanctions largely originate from case law of the CJEU on sex equality. ${ }^{70}$ However, certain procedural innovations result exclusively from legislative law-making. The most noticeable set of rules, for the purpose of this contribution, are the requirements that Member States shall ensure that interest groups 'may engage, either on behalf or in support of the complainant, with his or her approval, in any judicial and/or administrative procedure $^{, 71}$ and shall designate specialised bodies capable of providing assistance to victims pursuing complaints. ${ }^{72}$ Both the CJEU and the EU legislature, especially after the entry into force of the Lisbon Treaty and its ambitious antidiscrimination legal base in Article 19 TFEU, have thus sought to develop procedural tools in the service of EU equality policy.

67 See e.g. Directive 2004/113, Arts. 8(2) and 14.

68 See further: I. Ionescu \& R. Iordache, 'Discrimination and its Sanctions - Symbolic vs. Effective Remedies in European Anti-Discrimination Law' [2014/19] European Anti-Discrimination Law Review 11-24 and Case C-81/12 Asociația ACCEPT, judgment of 25 April 2013, not yet reported.

69 A. Stone Sweet, supra n. 15.

70 See also supra. See further L. Waddington \& M. Bell, 'More Equal than Others: Distinguishing EU Equality Directives' [2001/38] Common Market Law Review 587.

$71 \quad$ See supra Racial Equality Directive, Art. 7(2).

72 See supra Racial Equality Directive, Art. 13(2). 
This leads us to the second set of factors that explain the emergence of these common procedural rules; it is of a teleological nature. Article 19 TFEU grants the EU legislature the power to enact instruments with a view to 'combat discrimination' and Article 157 TFEU is destined to ensure 'the application' of the principle of equal treatment. Furthermore, the relevant directives seek to 'put into effect ${ }^{73}$ in the Member States the principle of equal treatment. Therefore, EU legislation on equality law is not presented as a set of common standards for the protection of non-economic values destined to facilitate the functioning of the internal market. ${ }^{74}$ Instead, it is introduced as a component of an ambitious project destined to "transform 75 societal habits and come closer to 'inter-personal equality per $\mathrm{se}^{77}$. In other words, $\mathrm{EU}$ anti-discrimination policy is not flanking the project of EU internal market making, but is a self-standing policy designed to give flesh to a fundamental right across as well as within the Member States.

Understood from such a perspective, EU equality law actually constitutes the 'first' 77 fundamental rights policy of the EU in so far as it provides for a set of tools adopted in order to transform societal habits. The procedural rules listed above are thus more than a mere - or technocratic - expression of the principle of 'effet utile' applied to EU anti-discrimination policy. The actual (judicial) activation of the right to equal treatment is a pre-condition to put the substance of the policy and its transformative/societal function into motion. In that sense, it appears logical that the said procedural rules are designed to support private applicants (and at times seek to compensate) in order to empower them to initiate vertical (individual v. public entity) as well as horizontal litigation (individual v. private entity) in situations that will mostly be completely deprived of any cross-border element (unlike most other EU policies). (Ed.), Regulating the Internal Market (Edward Elgar 2006) at 75 and N. Kosta, Fundamental
Rights in Internal Market Legislation (PhD Thesis defended at the European University Instit 2013).

75 See further E. Muir, 'The transformative function of EU equality law' [2013/21-5] European Review of Private Law 1231-1254.

76 F.W. Scharpf, supra note 16.

77 At least in terms of its historical origins; see also legislative developments since the middle of the 1990 s in the field of data protection: R. Gellert, K. de Vries, P. De Hert \& S. Gutwirth, 'A Comparative analysis of Anti-Discrimination and Data Protection Legislations', in: B. Custers, T. Calders, B. Schermer \& T. Zarsky (Eds), Discrimination and privacy in the Information Society Studies (Applied Philosophy, Epistemology and Rational Ethics 3, Springer 2013) p. 61. 


\section{The (Still?) Ugly Duckling: the Prohibition of Nationality Discrimination}

As pointed out in the introduction, the prohibition of nationality discrimination has long remained unaffected by the 'proceduralisation' process described in the previous section of this paper. Not only was there no comparable legislation but there also was a much less significant number of cases on the procedural dimension of the prohibition of nationality discrimination when compared in particular with sex equality. ${ }^{78}$

This situation changed in April 2014 when the EU legislature adopted a new Directive on 'measures facilitating the exercise of rights conferred on workers in the context of freedom of movement for workers'79 (the '2014 Directive', 'new' or 'Workers Directive'). This instrument is intended to enhance the enforcement of the rights of workers (with their family) to move and reside freely in the EU, in particular without being discriminated against on grounds of nationality. The new Directive indeed provides for a set of rules concerned with judicial proceedings.

The Workers Directive was adopted on the basis of a remarkably rapid legislative process. It was published in the official journal within a year of being tabled by the European Commission. ${ }^{80}$ This unusual feature may originate from different elements. There was a sense of urgency created by the desire to reach a compromise on the text before the European election in spring 2014, and to thereby avoid discussions on the proposal being postponed. Such a need to adopt legislation may also have been fed by the pressing anti-EU migrant tone in political discourses at domestic level. ${ }^{81}$ But an important factor may simply have been the fact that the Directive is largely modelled on pre-existing mechanisms of EU equality law; thus making its content less open to controversy.

78 See e.g. Case 222/86 Heplens ECR [1987] 4097, Case 8/77 Sagulo ECR [1977] 1495, Case 224/01 Köbler ECR [2003] I-10239. The scarcity of such cases may be precisely due to the fact that there were no legislative provisions helping the court to build along such lines, as in the area of EU sex equality law.

79 Supra note 20.

80 Proposal COM(2013)236 for a Directive on measures facilitating the exercise of rights conferred on workers in the context of freedom of movement for workers.

81 As reported for instance in: C. Barnard, 'Free movement of natural persons', in: C. Barnard \& S. Peers (OUP 2014), Sections 2.1. and 2.2; European Commission, 'Report on the Free Movement of Workers in Europe in 2011-2012' (available at ec.europa.eu/social, last accessed on 20.1.2015) 6o; European Commission, 'Study to analyse and assess the socio-economic and environmental impact of possible EU initiatives in the Area of Freedom of Movement for Workers, in particular with regard to the enforcement of current EU provisions' (VC/2011/0476, April 2012) 32-33. 
To what extent, then, do the provisions of this latest instrument relate to the common procedural law of EU equality policy? It will be argued that the new Directive largely replicates the common rules of EU equality policy (section 3.1). In that sense, it constitutes a significant step towards asserting the 'transformative' function of the prohibition of nationality discrimination (along with the other prongs of EU equality law that will be referred to below as 'mainstream EU equality law') - although several differences between the two prongs of EU equality law remain.

3.1 'So the First shall be the Last...': The Proceduralisation of EU Nationality Discrimination Policy

Similarities in the wording of the new Directive and earlier equality directives are undeniable and the differences that exist are not expected to have major practical consequences as will now be outlined. This sub-section analyses the provisions of the 2014 Directive in the same order as that used to introduce the common procedural law of EU equality policy and also directly quotes the main key provisions for the reader's ease.

\subsubsection{Access to Judicial and/or Administrative Procedures}

To start with, the Workers' Directive contains a provision on 'Defence of rights' that is very similar to its equivalent(s) in the five equality directives and ensures access to judicial procedures. ${ }^{82}$ Yet, Article 3 of the new Directive is more elaborate:

'1. Member States shall ensure that after possible recourse to other competent authorities including, where they deem it to be appropriate, conciliation procedures, judicial procedures, for the enforcement of obligations under Article 45 TFEU and under Articles 1 to 10 of Regulation (EU) No 492/2011, are available to all Union workers and members of their family who consider that they have suffered or are suffering from unjustified restrictions and obstacles to their right to free movement or who consider themselves wronged by a failure to apply the principle of equal treatment to them, even after the relationship in which the restriction and obstacle or discrimination is alleged to have occurred has ended.

82 Mere access to non-judicial procedures, such as administrative procedures, would thus not comply with the Directive. 
2. Member States shall ensure that associations, organisations, including the social partners, or other legal entities, which have, in accordance with the criteria laid down in their national law, practice or collective agreements, a legitimate interest in ensuring that this Directive is complied with, may engage, either on behalf of or in support of, Union workers and members of their family, with their approval, in any judicial and/or administrative procedure provided for the enforcement of the rights referred to in Article 1.

3. Paragraph 2 shall apply without prejudice to other competences and collective rights of the social partners, employees' and employers' representatives, where applicable, including the right to take action on behalf of a collective interest, under national law or practice.

4. Paragraph 2 shall apply without prejudice to national rules of procedure concerning representation and defence in court proceedings.

5. Paragraphs 1 and 2 of this Article shall apply without prejudice to national rules on time limits for enforcement of the rights referred to in Article 1. However, those national time-limits shall not render virtually impossible or excessively difficult the exercise of those rights'. ${ }^{83}$

Along with the definition of persons wronged being more narrow than under the mainstream equality directives ${ }^{84}$ and the reference to time-limits, ${ }^{85}$ the new Directive explicitly mentions the specific role of social partners in the employment sphere. Social partners should for instance be included among those legally entitled to act on behalf of or in support of private litigants. This could certainly have been an added value in the mainstream equality directives that relate to employment and are not so explicit on the matter. Yet, the relevant provision of the Workers Directive is also riddled with warnings against EU interference with domestic legal systems. On the one hand, the legislature wants to preserve the domestic definition of the competences and rights of social partners; a tone that is not to be considered without recalling the vivid debate

83 Workers Directive, Art. 3(1-5).

84 Compare with Coleman (Case C-303/o6 [2008] I-5603, paras 57-63) on discrimination-by-association. Note however that in that case the Court did not look at the enforcement provisions but at the definition of discrimination itself. Although Article 3(1) of Directive 2014/54 does not require access to judicial proceedings to all those being wronged, it does explicitly mention family members of workers; it may be that in practice this specification ensures a sufficiently broad personal scope of protection.

85 This aspect is more prescriptive than the other equality directives but it seems to merely codify the case law of the CJEU on time-limits: e.g. Case C-208/90 Emmott [1991] ECR I-4269, paras $16-17$. 
on the right to take collective action following the Viking and Laval cases. ${ }^{86}$ On the other hand, Member States are wary of intrusions into their procedural rules on representation and defence in court proceedings, thereby possibly expressing caution on further debate about collective redress.

\subsubsection{Partial Shift in the Burden of Proof}

In contrast, the Workers Directive is silent on the setting out of the burden of proof (unlike the mainstream equality directives). Although this constitutes a missed opportunity to provide clarity on the matter, this does not necessarily suggest that the actual test for breaches of the rules on the free movement of EU workers (and their families) is much different from the test for breaches of other prongs of EU equality law. In fact, the Court of Justice of the EU has for a long time adopted an approach based on whether the rule or behaviour challenged is capable of constituting an 'obstacle' to the workers (and his family's) right to free movement. ${ }^{87}$ According to this 'obstacles' approach, ${ }^{88}$ as soon as it is established that the act or practice may constitute a hindrance to free movement, it is for the defendant to establish the opposite. In essence, this 'obstacles' approach' thus amounts to a shift in the burden of proof. The Workers Directive actually seems to incorporate the obstacles' approach. It includes several references to the low requirement for creating a presumption of breach of free movement rules. For instance, Member States shall ensure that judicial procedures are available to 'Union workers and members of their family who consider that they have suffered or are suffering from unjustified restrictions and obstacles to their right to free movement. ${ }^{89}$

\subsubsection{Victimisation}

As part of the mainstream equality directives, the new Directive requires the introduction of a system for the protection of complainants against retaliation. The wording is almost identical to the corresponding articles in the other directives with the notable narrow definition of the notion of complainant since only the worker will be protected against victimisation (to the exclusion, for instance, of family members). ${ }^{90}$

86 See for instance: C. Barnard, 'A proportionate response to proportionality in the field of collective action' [2012/2] European Law Review 117-135.

87 See e.g. C-19/92 Kraus [1993] ECR I-1663, at para. 32.

88 See further G. Davies, 'Discrimination and beyond in European economic and social law' [2011/18-1-2] Maastricht Journal Of European And Comparative Law 7-28.

89 Workers Directive, Art. 3(1).

90 Workers Directive, Art. 3(6). 


\subsubsection{Specialised Bodies \& their Relationship to Courts}

Building on the main procedural innovation of the common procedural law of EU equality policy, Article 4 of the Workers Directive is devoted to 'Bodies to promote equal treatment and to support Union workers and members of their family'. Member States are required to designate (a) body

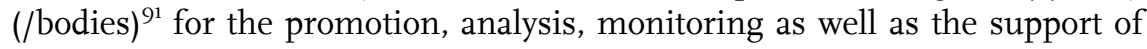
equal treatment and free movement rights of worker and family. Such bodies may also either be created specifically for that purpose or rely on existing structures so as to allow Member States a certain margin of manoeuvre depending on their own institutional model..$^{92}$ As in other prongs of EU equality law, the powers of these specialised bodies are important but remain limited. More specifically, the new Directive does not require that such bodies be given competence to trigger legal proceedings and the Member States are free to grant these entities the right to bring legal claims or not to do so. The model for the enforcement of EU equality law therefore remains primarily based on individual litigation..$^{93}$ Yet, interesting nuances in the wording of the 2014 Directive and that of its predecessors are noticeable. Article 4 reads as follows:

'1. Each Member State shall designate one or more structures or bodies ('bodies') for the promotion, analysis, monitoring and support of equal treatment of Union workers and members of their family without discrimination on grounds of nationality, unjustified restrictions or obstacles to their right to free movement and shall make the necessary arrangements for the proper functioning of such bodies. Those bodies may form part of existing bodies at national level which have similar objectives.

2. Member States shall ensure that the competences of those bodies include:

a. providing or ensuring the provision of independent legal and/or other assistance to Union workers and members of their family, without prejudice to their rights, and to the rights of associations, organisations and other legal entities referred to in Article 3;

b. acting as a contact point vis-à-vis equivalent contact points in other Member States in order to cooperate and share relevant information;

c. conducting or commissioning independent surveys and analyses concerning unjustified restrictions and obstacles to the right to free movement, or

$9^{1} \quad$ Or a structure/structures.

92 As outlined supra in section 2.2.4.

93 In contrast with public interest litigation. Although see the Workers Directive, recital (15):

'Member States are invited to examine the implementation of common principles for injunctive and compensatory collective redress mechanisms'. 
discrimination on grounds of nationality, of Union workers and members of their family;

$d$. ensuring the publication of independent reports and making recommendations on any issue relating to such restrictions and obstacles or discrimination;

e. publishing relevant information on the application at national level of Union rules on free movement of workers.

3. Member States shall communicate to the Commission the names and contact details of the contact points and any updated information or changes thereto. The Commission shall keep a list of contact points and shall make it available to the Member States.

4. Member States shall ensure that existing or newly created bodies are aware of, and are able to make use of, and cooperate with, the existing information and assistance services at Union level, such as Your Europe, SOLVIT, EURES, Enterprise Europe Network and the Points of Single Contact.

5. Where the tasks referred to in paragraph 2 are allocated to more than one body, Member States shall ensure that those tasks are adequately coordinated'.

The Workers Directive is slightly more forward looking than its predecessor when it comes to actively supporting private litigation to the extent that where specialised bodies provide assistance in legal proceedings, such assistance shall be cost free for claimants who lack the resources (although this is to be defined in accordance with national law or practice). ${ }^{94}$ Furthermore, the preamble of the Directive makes it clear that the specialised bodies may be asked to provide legal assistance in legal proceedings ${ }^{95}$ and should be encouraged to cooperate with (inter alia) labour inspectorates. ${ }^{96}$ These bodies may also be given competence to also cover the right to equal treatment without discrimination on grounds of nationality of all Union citizens exercising their right to free movement and the members of their family which is currently beyond the personal scope of the Workers Directive. ${ }^{97}$

Simultaneously, the legislature shows a certain anxiety as to the adequate implementation of the provision on specialised bodies. The Directive for instance calls on the Member States to pay specific attention to ensuring that these

\footnotetext{
Workers Directive, Art. 4(2).

Workers Directive, recital (17).

Workers Directive, recital (20).

Workers Directive, Art. 7.2.
} 
bodies function properly. ${ }^{98}$ There is also a concern that the choice by certain Member States to spread the tasks of specialised bodies among several organs domestically may dilute the activities of these organs. ${ }^{99}$ Coordination of the web of authorities created at European level and in charge of promoting the rights of workers to move and reside at European level should also be ensured. ${ }^{100}$

\subsubsection{Sanctions, Penalties, Compensation and Reparation}

As to the final component of the common procedural framework, the Workers Directive is once again almost silent. ${ }^{101}$ Although the case law of the CJEU is likely to partly fill this gap, this silence is to the detriment of clarity. It is also surprising that the legislature (and in particular the Member States) are so reluctant to adopt a provision on such matters while there are already prescriptive elements on this point in the latest equality directives. This illustrates an effort to combine relief with dissuasion, as explained above.

\subsection{A Significant Step towards the Assertion of the 'Transformative' Function of the Prohibition of Nationality Discrimination}

Although the parallel between the procedural rules on the (judicial) enforcement of the EU equality rules and of those concerned with restrictions to EU 'mobile'102 workers' rights are striking, there is very little in the wording of Directive 2014/54 to suggest that approximation of the regimes was intended - let alone desirable. Instead, the reasons for the adoption of the Directive seem more inward looking and relate to the observation that there remain significant obstacles to the free movement of workers in the EU. The absence of references to mainstream EU equality law may simply be due to the legal basis of the Directive, Article 46 TFEU, which relates to the free movement of workers (only).

This should not prevent external observers from reflecting on the implications of the de facto approximation of the procedural rules for the enforcement of 'mobile' workers' rights with that of mainstream EU equality law. In fact,

\footnotetext{
98 Workers Directive, Art. 4(1).

99 Workers Directive, Art. 4(5).

100 Workers Directive, Art. 4(4) and 4(2)(b) respectively. Note that similar provisions were inserted in the latest directives on sex equality: Directive 2006/54, Art. 20(2)(d) and Directive 2010/41, Art. 11(2)(d).

101 Although see the Workers Directive, recital (15), supra note 93.

102 This contribution acknowledges the existence of a sophisticated case law of the CJEU on the notion of a 'cross-border requirement' and does not expand on the matter.
} 
the greatest added value of the new Directive may lie precisely in the silent 'approximation' of the tools for the enforcement of EU equal treatment rights, bringing along the protection against nationality discrimination. By strengthening the enforcement of the prohibition against nationality discrimination by means of vertical as well as horizontal litigation, the EU legislature makes an attempt at modifying the enforcement culture of this field of EU law and actually asserts the transformative function of the prohibition of nationality discrimination. The Workers Directive thus does no less than to confirm that the rules on the free movement of workers enshrined in the Treaty should be given horizontal effect; ${ }^{103}$ the prohibition of nationality discrimination is now treated as a tool that should be used to correct inter-personal inequalities. Through a reflexive process, mediated by the adoption of procedural rules, the prohibition of nationality discrimination is thereby brought significantly closer to the transformative and human rights rationale that underlies the other grounds of discrimination.

This is not to deny that significant differences continue to exist in the design of the provisions on mainstream EU equality law on the one hand, and in the Workers Directive on the other. To start with, the 2014 Directive perpetuates the assumption that the prohibition of nationality discrimination enshrined in EU law only protects EU citizens who are 'mobile', to the exclusion of third country nationals and 'static' EU citizens. Secondly, the Workers Directive confirms the fragmentation of the approach of EU legislation on the matter. By only seeking to better enforce the rights of mobile EU workers and their families, the initiative sheds light on the lack of protection of other categories of mobile EU citizens such as non-economic and self-employed actors who may equally suffer from nationality discrimination. ${ }^{104}$

Finally, and importantly, the objective of the 2014 Directive is to address obstacles to the free movement of workers and their families - not only through the better enforcement of the prohibition of discrimination but also by tackling more 'neutral' obstacles to movement ${ }^{105}$ that may include language diversity or administrative barriers to movement. For instance owing to an enhanced obligation for the specialised bodies to act as a contact point, to exchange as well as disseminate information on free movement rules. ${ }^{106}$ This specificity of the role of specialised structures within the meaning of the 2014 Directive may not thus make it easy to merge them into classic bodies whose mandate is more

103 See also Case C-281/98, Angonese ECR [2000] I-4139; D. Martin, 'Comments on Angonese (et al.)' [2001/2-3] European Journal of Migration Law 431-433.

104 See supra note 97.

105 This is confirmed by the wording of Directive 2014/54, Arts. 4(1), 4(2)(c) and 4(2)(e).

106 See e.g. Workers Directive, Art. 4(3) and 4(2)(e). See also Art. 6(2) on the use of more than one official language of the institutions of the Union. 
focused on a classic approach to equal treatment. In that sense it is interesting to observe that the initial proposal by the Commission intended to limit the role of the specialised bodies to instances of nationality discrimination. ${ }^{107}$ Whether this is detrimental to the effectiveness of these specialised bodies will depend heavily on domestic approaches to the implementation of the new Directive.

\section{Conclusions}

The proceduralisation of EU equality law is a process that results from a combination of judicial and legislative initiatives, but with a significant influence of legal innovation through legislative law making (such as through specialised bodies). The underlying rationale behind the development of a set of common procedural rules is intimately related to the far reaching objective of EU equality policy to come closer to making the fundamental right to equal treatment a reality across, as well as within, the Member State.

The more recent proceduralisation of the legal regime on the prohibition of nationality discrimination against mobile EU workers has been primarily driven by a distinct, internal market making, dynamic. However, the de facto alignment with the procedural rules of the other prongs of EU equality law allows for a strengthening of the fundamental rights rationale and transformative function of the prohibition of nationality discrimination. Nationality discrimination must now forcefully be tackled through the same type of tools as those available to combat discrimination on grounds of sex, race/ethnic origin, religion/belief, sexual orientation, disability and age. And the nature of EU intervention in this field must be understood as intended to address public as well as private nationality bias despite long standing uncertainties on the matter. ${ }^{108}$

With this new instrument in hand, the current challenge is twofold. First, further efforts towards alignment would be welcome. This could bring the procedural rules on the prohibition of nationality discrimination against 'mobile' EU workers one step closer to the wording of the equality directives - on the burden of proof and sanctions/compensation for instance. Furthermore, greater approximation with the other prongs of EU equality would imply the proceduralisation also of the prohibition of nationality discrimination against service providers as well as 'mobile' non-economic EU citizens, for instance. ${ }^{109}$

107 Proposal COM(2013)236, supra note 80, Art. 5 .

108 See supra note 103 .

109 Interesting procedural provisions have recently been adopted in relation to posted workers in the context of the free movement of services. Unlike the Workers Directive, this new instrument is tailored to the specific and complex situation of posted workers: Directive $2014 / 67$ on the enforcement of Directive $96 / 71$ concerning the posting of workers in the framework of the 
Second, future reflections on proceduralisation are likely to include debates on the role of collective action and redress mechanisms so as to bridge the gap between private and public enforcement mechanisms. ${ }^{110}$ This, and perhaps more importantly, whether the 2014 Directive and possible follow ups will genuinely contribute to a new enforcement culture, depends highly on how seriously it is taken at the domestic as well as European levels. One can only hope that the European Commission will be vigilant on this matter and pressure the Member States to give full effect to these procedural rules.

provision of services and amending Regulation 1024/2012 on administrative cooperation through the Internal Market Information System OJ [2014] L159/11; see in particular Art. 11.

110 See further: M. Dawson \& E. Muir, 'Individual, institutional and collective vigilance in protecting fundamental rights in the EU: lessons from the Roma' [2011/48-3] Common Market Law Review 751-775 and supra notes 44 to 46. 